Please quote as: Söllner, M. (2015): Understanding Trust in Information Systems The Impact of Trust in the System and in the Provider. In: 75th Annual Meeting of the Academy of Management, Vancouver, BC, Kanada 


\section{UNDERSTANDING TRUST IN INFORMATION SYSTEMS -THE IMPACT OF TRUST IN THE SYSTEM AND IN THE PROVIDER}

\section{$\underline{\text { Author }}$}

Matthias Söllner, University of St. Gallen \& Kassel University, matthias.soellner@unisg.ch \& soellner@uni-kassel.de

\section{Acknowledgement}

The results presented in this article were partly developed in the research project "The Impact of the Digital Transformation on our Understanding of Key Drivers of Technology Usage The Case of Trust" funded by the Basic Research Fund of University of St.Gallen. I thank the Research Committee of the University of St.Gallen for supporting my research. For further information on the project please see: https://www.alexandria.unisg.ch/Projekte/228929 


\title{
UNDERSTANDING TRUST IN INFORMATION SYSTEMS -THE IMPACT OF TRUST IN THE SYSTEM AND IN THE PROVIDER
}

\begin{abstract}
To provide value for businesses, information systems (IS) must be adopted and used by their intended users, no matter whether a company focuses on selling IS on the market (external users) or whether IS are used to keep the business going (internal users). One of the most important factors driving the adoption and use is trust. The goal of this paper is to provide a first evaluation of a conceptual piece claiming a) that users distinguish between their trust in an IS and the provider of this IS and b) that both kinds of trust are important for the success sustainable success of IS providers, and thus should be studied simultaneously. To evaluate the claims, a research model is developed and evaluated using data of 234 students during the introduction of a new IS at an university. The results provide empirical support for both claims, since the correlation between the two trust constructs is low, and the nomological networks are different. Regarding the importance of both constructs, trust in the IS is found to have an important impact of the use of the IS, whereas trust in the provider is a major driver of the users' loyalty.
\end{abstract}

Keywords: trust, information systems, trust in the information system, trust in the provider 


\section{REFERENCES}

Benbasat, I., \& Barki, H. 2007. Quo vadis TAM? Journal of the Association for Information Systems, 8(4).

Cenfetelli, R., \& Bassellier, G. 2009. Interpretation of Formative Measurement in Informations Systems Research. MIS Quarterly, 33(4): 689-707.

Chesbrough, H. W. 2003. Open innovation: The new imperative for creating and profiting from technology. Boston, Mass.: Harvard Business School Press.

Chin, W. W. 1998. The Partial Least Squares Approach to Structural Equation Modeling. In G. A. Marcoulides (Ed.), Modern Methods For Business Research. London: LEA.

Chin, W. W., \& Newsted, P. R. 1999. Structural Equation Modeling Analysis with Small Samples Using Partial Least Squares. In R. H. Hoyle (Ed.), Statistical Strategies For Small Sample Research: $308-341$. Thousand Oaks: Sage.

Chin, W. W., Thatcher, J. B., \& Wright, R. T. 2012. Assessing common method bias: problems with the ULMC technique. MIS Quarterly, 36(3): 1003-1019.

Chwelos, P., Benbasat, I., \& Dexter, A. S. 2001. Research Report: Empirical Test of an EDI Adoption Model. Information Systems Research, 12(3): 304-321.

Davis, F. D. 1989. Perceived Usefulness, Perceived Ease of Use, and User Acceptance of Information Technology. MIS Quarterly, 13(3): 319-340.

Diamantopoulos, A., \& Siguaw, J. A. 2006. Formative Versus Reflective Indicators in Organizational Measure Development: A Comparison and Empirical Illustration. British Journal of Management, 17(4): 263-282.

Dimoka, A., Pavlou, P. A., \& Davis, F. D. 2011. Research Commentary--NeuroIS: The Potential of Cognitive Neuroscience for Information Systems Research. Information Systems Research, 22(4): 687-702.

Ebert, T. 2009. Facets of Trust in Relationships - A Literature Synthesis of Highly Ranked Trust Articles. Journal of Business Market Management, 3(1): 65-84.

Frey, R.-V., Bayon, T., \& Totzek, D. 2013. How Customer Satisfaction Affects Employee Satisfaction and Retention in a Professional Services Context. Journal of Service Research, 16(4): 503-517.

Friedman, B., Khan, Peter H. Jr., \& Howe, D. C. 2000. Trust online. Commun. ACM, 43(12): 34-40.

Gefen, D. 2004. What Makes an ERP Implementation Relationship Worthwhile: Linking Trust Mechanisms and ERP Usefulness. Journal of Management Information Systems, 21(1): 263-288.

Gefen, D., Benbasat, I., \& Pavlou, P. A. 2008. A Research Agenda for Trust in Online Environments. Journal of Management Information Systems, 24: 275-286. 
Gefen, D., Karahanna, E., \& Straub, D. W. 2003. Trust and TAM in Online Shopping: An Integrated Model. MIS Quarterly, 27(1): 51-90.

Gefen, D., Rigdon, E. E., \& Straub, D. W. 2011. Editor's Comments: An Update and Extension to SEM Guidelines for Administrative Social Science Research. MIS Quarterly, 35(2): iii-xiv.

Gefen, D., \& Straub, D. W. 2004. Consumer trust in B2C e-Commerce and the importance of social presence: experiments in e-Products and e-Services. Omega, 32(6): 407-424.

Guilabert, M. B. 2005. Attitudes Toward Consumer-Customized High-Tech Products: The Role of Perceived Usefulness, Perceived Ease of Use, Technology Readiness, and Customer Customization Sensitivity.

Hair, J. F., Hult Thomas M., Ringle, C. M., \& Sarstedt, M. 2013. A primer on partial least squares structural equation modeling (PLS-SEM). Thousand Oaks, CA, USA: Sage.

Hair, J. F., Sarstedt, M., Ringle, C. M., \& Mena, J. A. 2012. An assessment of the use of partial least squares structural equation modeling in marketing research. Journal of the Academy of Marketing Science, 40(3): 414-433.

Halvorsen, K. E. 2001. Assessing public participation techniques for comfort, convenience, satisfaction, and deliberation. Environmental management, 28(2): 179-186.

Iacovou, C. L., Thompson, R. L., \& Smith, H. J. 2009. Selective Status Reporting in Information Systems Projects: A Dyadic-Level Investigation. MIS Quarterly, 33(4): 785A5.

Jarvenpaa, S. L., \& Leidner, D. E. 1999. Communication and Trust in Global Virtual Teams. Organization Science, 10(6): 791-815.

Jarvis, C. B., Mackenzie, S. B., \& Podsakoff, P. M. 2003. A Critical Review of Construct Indicators and Measurement Model Misspecification in Marketing and Consumer Research. Journal of Consumer Research, 30(2): 199-218.

Jian, J.-Y., Bisantz, A. M., \& Drury, C. G. 2000. Foundations for an empirically determined scale of trust in automated systems. International Journal of Cognitive Ergonomics, 4(1): $53-71$.

Kankanhalli, A., Tan, Bernard C. Y., \& Kwok-Kee, W. 2005. Contributing Knowledge to Electronic Knowledge Repositories: An Empirical Investigation. MIS Quarterly, 29: 113143.

Kiesler, S., \& Sproull, L. 1997. "Social” human-computer interaction. In B. Friedman (Ed.), Human values and the design of computer technology: 191-199: Center for the Study of Language and Information.

Komiak, S., \& Benbasat, I. 2006. The Effects of Personalization and Familiarity on Trust and Adoption of Recommendation Agents. MIS Quarterly, 30(4): 941-960.

Lee, J. D., \& See, K. A. 2004. Trust in Automation: Designing for Appropriate Reliance. Human Factors, 46(1): 50-80. 
Leimeister, J. M., Ebner, W., \& Krcmar, H. 2005. Design, Implementation, and Evaluation of Trust-Supporting Components in Virtual Communities for Patients. Journal of Management Information Systems, 21(4): 101-135.

Lowry, P. B., Vance, A., Moody, G., Beckman, B., \& Read, A. 2008. Explaining and Predicting the Impact of Branding Alliances and Web Site Quality on Initial Consumer Trust of E-Commerce Web Sites. Journal of Management Information Systems, 24(4): 199-224.

Luhmann, N. 1979. Trust and power. Chichester, UK: Wiley.

Mayer, R. C., \& Davis, J. H. 1999. The Effect of the Performance Appraisal System on Trust for Management: A Field Quasi-Experiment. Journal of Applied Psychology, 84(1): 123136.

Mayer, R. C., Davis, J. H., \& Schoorman, F. D. 1995. An Integrative Model of Organizational Trust. Academy of Management Review, 20(3): 709-734.

McKnight, D. H., Carter, M., Thatcher, J. B., \& Clay, P. F. 2011a. Trust in a specific technology: An investigation of its components and measures. ACM Transaction on Management Information Systems, 2(2).

McKnight, D. H., Choudhury, V., \& Kacmar, C. 2002b. Developing and Validating Trust Measures for e-Commerce: An Integrative Typology. Information Systems Research, 13(3): 334-359.

McKnight, D. H., Choudhury, V., \& Kacmar, C. 2002. The impact of initial consumer trust on intentions to transact with a web site: a trust building model. The Journal of Strategic Information Systems, 11(3-4): 297-323.

Menzel, S., Buchecker, M., \& Schulz, T. 2013. Forming social capital--does participatory planning foster trust in institutions? Journal of environmental management, 131: 351362.

Morgan, R. M., \& Hunt, S. D. 1994. The Commitment-Trust Theory of Relationship Marketing. Journal of Marketing, 58(3): 20.

Nass, C., Steuer, J., \& Tauber, E. R. 1994. Computers are social actors. In B. Adelson, S. Dumais \& J. Olson (Eds.), Proceedings of the SIGCHI Conference on Human Factors in Computing Systems: 72-78.

Ortiz de Guinea, \& Markus, M. L. 2009. Why break the habit of a lifetime? rethinking the roles of intention, habit, and emotion in continuing information technology use. MIS Quarterly, 33(3): 433-444.

Pavlou, P. A., \& Dimoka, A. 2006. The Nature and Role of Feedback Text Comments in Online Marketplaces: Implications for Trust Building, Price Premiums, and Seller Differentiation. Information Systems Research, 17(4): 392-414.

Petter, S., Straub, D., \& Rai, A. 2007. Specifying Formative Constructs in Information Systems Research. MIS Quarterly, 31: 623-656. 
Piller, F. T. 2004. Mass Customization: Reflections on the State of the Concept. International Journal of Flexible Manufacturing Systems, 16(4): 313-334.

Podsakoff, P. M., Mackenzie, S. B., Lee, J.-Y., \& Podsakoff, N. P. 2003. Common method biases in behavioral research: A critical review of the literature and recommended remedies. Journal of Applied Psychology, 88(5): 879-903.

Riedl, R., Mohr, P., Kenning, P., Davis, F., \& Heekeren, H. 2011. Trusting Humans and Avatars: Behavioral and Neural Evidence. International Conference on

Information Systems (ICIS) 2011.

Ringle, C. M., Sarstedt, M., \& Straub, D. W. 2012. A Critical Look at the Use of PLS-SEM in MIS Quarterly. MIS Quarterly, 36(1): iii-xiv.

Ringle, C. M., Wende, S., \& Will, A. 2005. SmartPLS 2.0. Hamburg.

Rivard, S., \& Lapointe, L. 2012. Information Technology Implementers' Response to User Resistance: Nature and Effects. MIS Quarterly, 36(3): 897-920.

Schumann, J. H., Wangenheim, F. v., Stringfellow, A., Zhilin Yang, Praxmarer, S., Jimenez, F. R., Blazevic, V., Shannon, R. M., G., S., \& Komor, M. 2010. Drivers of Trust in Relational Service Exchange: Understanding the Importance of Cross-Cultural Differences. Journal of Service Research, 13(4): 453-468.

Sharma, R., Yetton, P., \& Crawford, J. 2009. Estimating the Effect of Common Method Variance: The Method-Method Pair Technique with an Illustration from TAM Research. MIS Quarterly, 33(3): 473-A13.

Singh, J., \& Sirdeshmukh, D. 2000. Agency and trust mechanisms in consumer satisfaction and loyalty judgments. Journal of the Academy of Marketing Science, 28(1): 150-167.

Söllner, M. 2014. Deriving Trust Supporting Components for Ubiquitous Information Systems. Kassel, Hess: Kassel University Press.

Söllner, M., Hoffmann, A., Hoffmann, H., Wacker, A., \& Leimeister, J. M. 2012. Understanding the Formation of Trust in IT Artifacts. International Conference on Information Systems (ICIS) 2012.

Söllner, M., \& Leimeister, J. M. 2013. What We Really Know about Antecedents of Trust: A Critical Review of the Empirical Information Systems Literature on Trust. In D. Gefen (Ed.), Psychology of trust. New research: 127-155. Hauppauge, New York: Nova Science Publishers.

Söllner, M., Pavlou, P. A., \& Leimeister, J. M. 2013. Understanding Trust in IT Artifacts - A new Conceptual Approach. Academy of Management Annual Meeting, Orlando, Florida, $\boldsymbol{U S A}$.

Vance, A., Elie-Dit-Cosaque, C., \& Straub, D. W. 2008. Examining Trust in Information Technology Artifacts: The Effects of System Quality and Culture. Journal of Management Information Systems, 24(4): 73-100. 
Venkatesh, V., \& Bala, H. 2008. Technology Acceptance Model 3 and a Research Agenda on Interventions. Decision Sciences, 39(2): 273-315.

Venkatesh, V., Morris, M. G., Davis, G. B., \& Davis, F. D. 2003. User Acceptance of Information Technology: Toward a Unified View. MIS Quarterly, 27(3): 425-478.

Wang, W., \& Benbasat, I. 2005. Trust in and Adoption of Online Recommendation Agents. Journal of the Association for Information Systems, 6(3): 72-101.

Zeithaml, V. A., Berry, L. L., \& Parasuraman, A. 1996. The Behavioral Consequences of Service Quality. Journal of Marketing, 60(2): 31-46. 